(C) The Author(s), 2021. Published by Cambridge University Press on behalf of the Arizona Board of Regents on behalf of the University of Arizona. This is an Open Access article, distributed under the terms of the Creative Commons Attribution licence (http://creativecommons.org/licenses/by/4.0/), which permits unrestricted re-use, distribution, and reproduction in any medium, provided the original work is properly cited.

\title{
THE NEKSEL $\varnothing$ FISH WEIR AND MARINE RESERVOIR EFFECT IN NEOLITHIZATION PERIOD DENMARK
}

\author{
Anders Fischer ${ }^{1,2 *}$ (D) Jesper Olsen ${ }^{3}$ (D) \\ ${ }^{1}$ Sealand Archaeology, Gl. Roesnaesvej 27, 4400 Kalundborg, Denmark \\ ${ }^{2}$ Department of Historical Studies, University of Gothenburg, 40530 Gothenburg, Sweden \\ ${ }^{3}$ Aarhus AMS Centre (AARAMS), Department of Physics and Astronomy, Aarhus University, Ny Munkegade 120, \\ DK-8000 Aarhus C, Denmark
}

\begin{abstract}
The Nekselø Wickerwork provides an unusually solid estimate on the marine reservoir age in the Holocene. The basis for this result is a 5200-year-old fish weir, built of hazel wood with a brief biological age of its own. Oysters settled on this construction. They had lived only for a short number of years when the fence capsized and was covered in mud and the mollusks suffocated. Based on the difference in radiocarbon $\left({ }^{14} \mathrm{C}\right)$ age between accelerator mass spectrometry (AMS) samples of oyster shells and wood, respectively, the marine reservoir age for this site is estimated to $273 \pm 18{ }^{14} \mathrm{C}$ years. Re-evaluations of previously produced data from geological and archaeological sites of Holocene date in the Danish archipelago indicate marine reservoir ages in the same order as that of the Wickerwork. Consequently, we recommend the use of the new value, rather than the ca. $400{ }^{14} \mathrm{C}$ years hitherto favored, when correcting for the dietary induced reservoir effect in radiocarbon dates of humans and animals from the Late Mesolithic and Early Neolithic periods of this region.
\end{abstract}

KEYWORDS: Denmark, fish weir, Kattegat, marine reservoir age, Neolithic, oyster.

\section{INTRODUCTION}

Uncertainty as to the accurate value of the reservoir effect in radiocarbon $\left({ }^{14} \mathrm{C}\right)$ dates is a considerable challenge to prehistorians, geneticists, etc. in their attempts at reconstructing the course of events in cultural and population history. The neolithization (introduction of food production based on domesticates of Middle Eastern origin) is an instance where such uncertainty is severely hampering scientific progress. During this transformation process, which took place over major parts of the Old World, fishing-hunting-gathering was replaced with cattle husbandry and cereal production alongside dramatic changes in material culture, ritual behavior and population genetics. Denmark has a central role in the study of this epoch-making episode (Fischer and Kristiansen 2002). It took place in this country in the decades/centuries around $3950 \mathrm{BC}$ or ca. $5100{ }^{14} \mathrm{C}$ years BP (Persson 1999; Fischer 2002; Sørensen 2014). Many of the radiocarbon dates essential to the study of the Mesolithic-Neolithic transformation process in Denmark are significantly influenced by the marine reservoir effect (e.g. Tauber 1981a and 1981b; Andersen 1991 and 1993; Persson 1999; Price et al. 2007) and a clarification of the reservoir age applying specifically to the period and geographic area in question is therefore much needed. This applies, not least, to the sorting out of the relative and absolute chronology of the many human skeletons that are currently subject to genetic study aiming e.g. at population history reconstruction. The dietary protein intake from marine sources among these neolithization period individuals varied from ca. $0 \%$ to ca. $90 \%$ (Fischer et al. 2007).

Oceans are depleted in ${ }^{14} \mathrm{C}$ content relative to the coeval atmosphere. The apparent ${ }^{14} \mathrm{C}$ age difference between oceanic surface water and the contemporaneous atmosphere at a single point in time is called the marine reservoir age, $\mathrm{R}(\mathrm{t})$ (Stuiver and Polach 1977; Stuiver and

\footnotetext{
*Corresponding author. Email: sealandarchaeology@gmail.com.
} 
Braziunas 1993). Prior to the most recent update of the marine calibration curve (Marine20) the marine reservoir age, $\mathrm{R}(\mathrm{t})$, was estimated using a $2 \mathrm{D}$ box model representing the modelled global ocean (Reimer et al. 2013; Heaton et al. 2020). Thus with Marine13 the global reservoir age amounted to about $400{ }^{14} \mathrm{C}$ years and was roughly constant in time (e.g. Reimer et al. 2013). However, Marine20 is calculated using a 3D ocean general circulation model taking into account the temporal changes in the atmospheric ${ }^{14} \mathrm{C}$ content as well as carbon cycle dynamics (Heaton et al. 2020). As a consequence, the global reservoir age, $\mathrm{R}(\mathrm{t})$, can no longer be considered constant. For the Holocene, $\mathrm{R}(\mathrm{t})$ varies between 380 and $674{ }^{14} \mathrm{C}$ years with an average offset of $500 \pm 60{ }^{14} \mathrm{C}$ years. In the early Holocene prior to ca. 6000 $\mathrm{BC}$ and between ca. $3000 \mathrm{BC}$ and $600 \mathrm{AD}$ the global average reservoir age is ca. $465{ }^{14} \mathrm{C}$ years, whereas the period between 6000-3000 BC and from $600 \mathrm{AD}$ towards the present are characterized by reservoir ages around $550{ }^{14} \mathrm{C}$ years (Heaton et al. 2020).

Previously a reservoir age of $400{ }^{14} \mathrm{C}$ years was frequently applied when correcting for marine reservoir effect in archaeological and geological samples from Holocene Denmark (e.g. Heinemeier et al. 1993; Ascough et al. 2009; Olsen et al. 2019; cf. Tauber 1990; Rasmussen 2013). A confirmation of this approach may be seen in data from the neolithization period, retrieved from a sediment core in marine sediments at the site of Kilen (Figure 1), which those days had an effective exchange of water with the North Sea (Petersen 1975; Christensen et al. 2004). Three paired samples of marine shell and terrestrial botanical material of negligible biological own age from this site reveal a reservoir age of 351-393 ${ }^{14} \mathrm{C}$ years (Philippsen et al. 2013).

For Danish marine areas, however, the modern reservoir age, $\mathrm{R}(\mathrm{t})$, is regionally highly variable, ranging between ca. 250 and $900{ }^{14} \mathrm{C}$ years (see Figure 1). The numerically highest values are seen in fjord environments with a considerable influx of ${ }^{14} \mathrm{C}$ depleted groundwater. In contrast, values less than 400 years are recorded in the Danish archipelago (Kattegat region), where waters from the North Sea/North Atlantic and the Baltic Sea are mixing. The latter receives precipitation from substantial parts of northern Europe, resulting in a steady outflow of water with a reservoir age of 250-300 years into the Danish archipelago (Olsen et al. 2017b; cf. Lougheed et al. 2013; Philippsen 2018). In the neolithization period salinity in this archipelago was generally somewhat higher than now, possibly due to a higher exchange of water with the North Sea (Lewis et al. 2020). This most likely implies correspondingly higher reservoir ages in accordance with North Atlantic Ocean values. Because the changes between IntCal13 and IntCal20 overall are small, the above-mentioned reservoir ages, R(t), may still be considered accurate (Reimer et al. 2013, 2020).

To take into account regional effects such as deep-water upwelling or freshwater inputs the regional reservoir offset, $\Delta \mathrm{R}(\mathrm{t})$, is defined as the deviations in reservoir age from the global marine calibration curve (Stuiver et al. 1986). A study based on 27 paired samples of terrestrial plant material and shells from marine mollusks respectively, derived from sediment cores of Holocene to recent date at three sites in fjords and inlets in the Danish archipelago, also produced highly varied estimates of reservoir age. The $\Delta R(t)$ values calculated using Marine09 for the relatively ocean-oriented sites of Horsens Fjord and Tempelkrog ranged from -80 to 360 and 145 to $400{ }^{14} \mathrm{C}$ years respectively, while Skælskør Nor ranged from 375 to $890{ }^{14} \mathrm{C}$ years. The significantly larger values of the latter site with its relatively restricted exchange of water with the open sea can, again, be explained as a result of a significant influx of groundwater (Olsen et al. 2009; Reimer et al. 2009). However, due to the methodological change in calculating the marine reservoir age taken 
(A)

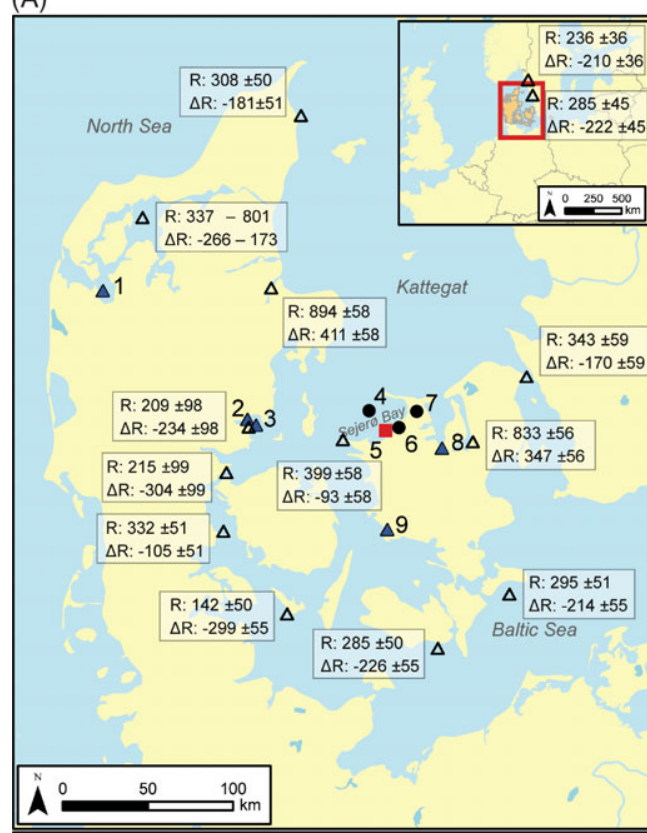

- Fish weir

- Burial

$\Delta$ Marine sediments etc.

\begin{abstract}
1. Kilen
2. Horsens Fjord

3. Hjarnø Sund
\end{abstract}

(B)

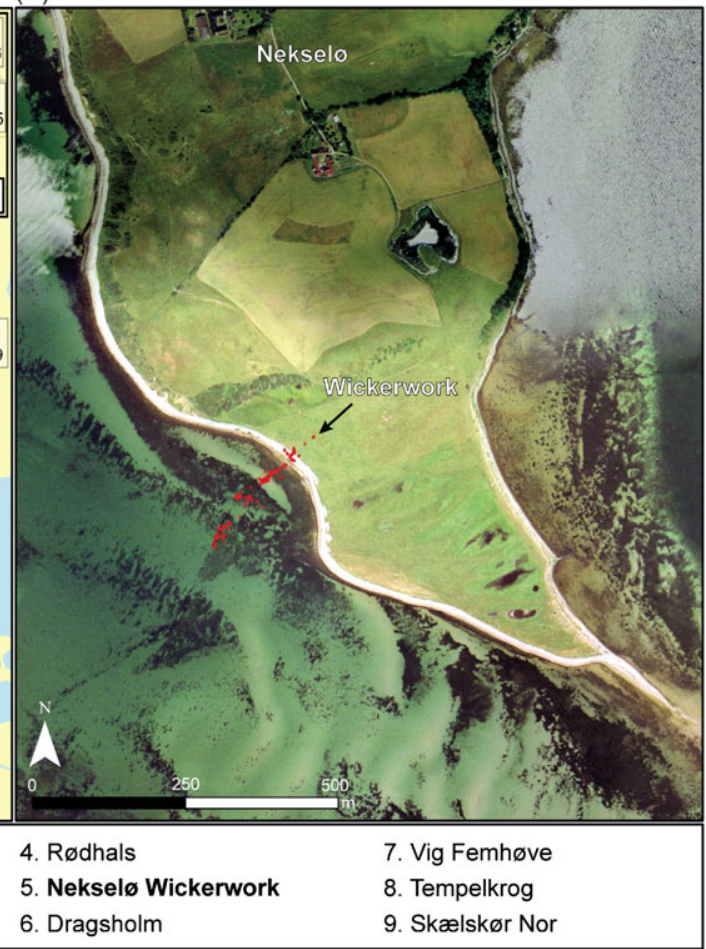

Figure 1 The location of the Nekselø Wickerwork and other sites and marine areas mentioned in the text. The reservoir ages indicated are extracted from the Marine Reservoir Database (http://calib.org/marine/) and derive from Håkansson (1969), Olsson (1980), Heier-Nielsen et al. (1995), and Lougheed et al. (2013). Only suspension feeders are included, and all samples are collected between 1861 and 1952 AD. For sites/marine areas with multiple measurement the weighted average of both $\mathrm{R}$ and $\Delta \mathrm{R}$ are shown. Insert to the right shows the present-day topography of the Wickerwork with a relative sea-level about $2.5 \mathrm{~m}$ lower than at the time of erection of the fish weirs.

for the Marine20 calibration curve these regional reservoir offset values are no longer valid and will need recalculating before they can be used with Marine20. Nonetheless, it can be concluded that the reservoir ages, $\mathrm{R}(\mathrm{t})$ and likely also the regional reservoir offset, $\Delta \mathrm{R}(\mathrm{t})$, in Danish marine waters are both site-specific and time-specific (Olsen et al. 2009; cf. Lougheed et al. 2013; Olsen et al. 2017b; Philippsen 2018).

More recently, a study from Hjarnø Sund, a site in the Danish archipelago characterized by an effective water exchange with the open sea, has produced two paired dates. Both are based on a marine mollusk shell (Ostrea edulis) and a charcoal, respectively. In these cases, the age difference between the marine and the terrestrial sample is $410 \pm 69$ and $327 \pm 70{ }^{14} \mathrm{C}$ years (Larsen et al. 2018). Since both terrestrial samples derive from hazel wood (Corylus sp.) of unknown biological age there is a risk that these values might be decades too high. In addition, a risk of re-deposition of re-worked material from older sediments cannot be fully excluded-neither in this latter case nor the above-mentioned four Holocene cases-again potentially adding to the risk that the values mentioned exaggerate the marine reservoir age.

Such risks do not pertain to the Nekselø Wickerwork assemblage of paired marine and terrestrial samples presented below. Additionally, this site represents a more open water 
condition and should consequently be influenced by local reservoir effect factors to a lesser extent than seen in the above-mentioned studies. Like with the marine calibration curve the calculated reservoir ages from Nekselø apply to surface-near waters. Noteworthy, this is where almost all biological activity relevant to human diet will have come from.

\section{THE WICKERWORK OF NEKSEL $\varnothing$}

During the final centuries of the Mesolithic and especially in the initial centuries of the Neolithic, weir fishing took place at a considerable scale off the southwest coast of the island of Nekselø in the Danish archipelago (Figure 1). It was probably migrating eel that were trapped in the up to 200-m-long wood constructions (Figures 2-3). The archaeological remains consist of numerous wattle panels made from rods of hazel in combination with hundreds of vertical supporting poles (Pedersen 1995, 2013; Bartholin 1996; Fischer 2006; Pedersen et al. 2017, 2018). After having been hidden in marine sediments for millennia the wood constructions saw the light of day again some years ago due to sea floor erosion (Fischer 2011).

The landscape characteristics in the vicinity of the Nekselø Wickerwork imply that the local supply of freshwater and ground water to the site was minimal. Moreover, the weirs were built into open sea at the most wind and wave exposed side of the island, thus granting an effective mixing of waters (Figure 1).

The 18 previously published ${ }^{14} \mathrm{C}$ dates of constructional wood from the fish weirs at the site span the interval of time ca. $5600-4300{ }^{14} \mathrm{C}$ BP (Fischer 2007; Fischer and Jensen 2018). In South Scandinavian archaeological terminology this period is equivalent with the final part of the Late Mesolithic Ertebølle Culture and most of the chronological range of the subsequent Neolithic Funnel Beaker Culture (Nielsen 1993; Fischer 2002).

Oyster (Ostrea edulis) thrived at the Nekselø Wickerwork. This species prefers saline conditions and demands a firm substrate with little silting on which to settle (Milner 2002: 10; Lewis et al. 2016), and the fish weirs served this need very well (Figure 3). On the surface of oyster valves from the site a round-bottom furrow is often seen. A couple of especially well-defined examples are shown in Figure 4. They represent the contact region between mollusk and constructional wood.

Central to the present study are two wattle panels (Figure 2), that were joined together by the tongue-and-groove principle (cf. Pedersen 1997) and consequently are absolutely contemporaneous. Originally, they were part of a ca. 4-m-high fence on the seabed. This construction is recorded in places of erosion at a straight line over a distance of some $40 \mathrm{~m}$. Additional data for this study derives from a nearly upright-standing wickerwork (section E, Figure 3), located some further $40 \mathrm{~m}$ out in the sea.

The aforementioned pair of panels, labeled $\mathrm{C} 1$ and $\mathrm{C} 2$, were located more than $100 \mathrm{~m}$ from the coeval seashore. Rough weather made them tip over and lay down horizontally (Figure 2). The remarkable preservation of their hazel rods implies that during their time of use they were only directly exposed to sea water for a short while. Otherwise, the disintegrating actions of bacteria, fungi, crustacea, etc. (cf. Gregory and Matthiesen 2018) would have altered their surfaces significantly (Figure 2B). The 4 years of growth-inferred by direct visual inspection of the hinges and surfaces of the shells of two oyster that had lived on these panels-could very 
(A)

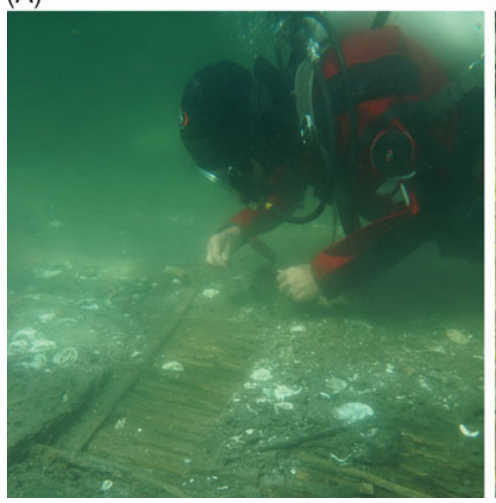

(B)

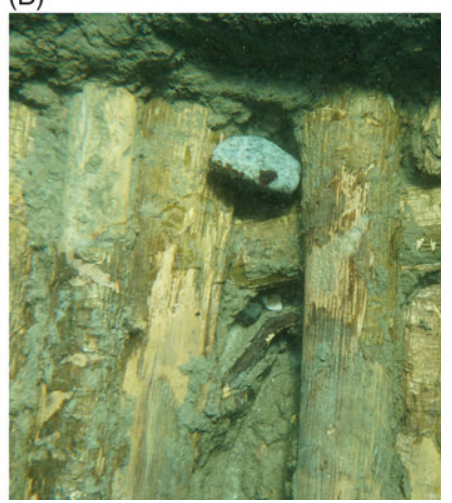

Figure 2 Wattle panel C1 of the Wickerwork. In the Neolithic it was part of a fish weir that was knocked down by the sea and rapidly covered in marine mud so that oysters could no longer live on the wood: (A) overview during clearing up of the panel after recent sea-floor erosion; (B) close-up of a part untouched by present-day erosion-to some extent, however, with scars and loss of bark arisen during excavation. When revealed by archaeologists, these hazel rods were preserved in such good condition that their bark had still kept much of its original color and texture. The unbroken deposits of silty gyttja from the stakes upward support the impression of a rapid and permanent covering in sea-bed sediments. (Photos: Anne Marie Eriksen, Danish National Museum 2016.)

well represent the whole length of time between the erection and capsizing of the construction, the latter event causing the mollusks to suffocate.

The wooden building materials and the oysters sitting on them are not absolutely contemporaneous. When judging the scale of this time gap the following aspects should be considered: wood anatomical inspections of a large assemblage of rods and poles from the Wickerwork have revealed that felling took place in late winter/early spring (Pedersen et al. 2017). Experience from practical experiments (cf. Pedersen and Jørgensen 2006) suggests that the weaving of stakes into panels began soon after. Their installation in the water could wait until the close of summer, when eels from the Baltic Sea and the Danish archipelago began to migrate towards their spawning ground in the Atlantic (Pedersen 2013). Present-day experiments indicate that if stored on land for a year hazel panels will lose resilience to a degree that would make them unfit as constructional elements in weirs for eel fishing in the open sea. Additionally, written sources on weir fishing in northern Europe in historical time indicate that when used in sea water hazel panels usually had to be replaced within a maximum of 4 years (Schmelling 1971, 112; cf. Brinkhuizen 1983). In sum, we can expect a time gap of a half to four years between the harvest of the rods in the Nekselø Wickerwork and the beginning of the growth of the oysters found on the wattle.

\section{SAMPLING AND DATING WOOD AND OYSTER SHELLS}

Three paired sets of oyster shells were observed still firmly attached to the constructional wood that once served as their living place. Two of these relate to wattle panels $\mathrm{C} 1$ and $\mathrm{C} 2$ (Figure 5A). The third pair of solidly attached shells was found on a supporting pole by panel E (Figures 3 and 5B). The potential of using these combinations of shell and wood for high precision estimates of marine reservoir age was realized instantaneously. Field and laboratory procedures could therefore be arranged to make the most of the opportunity. 


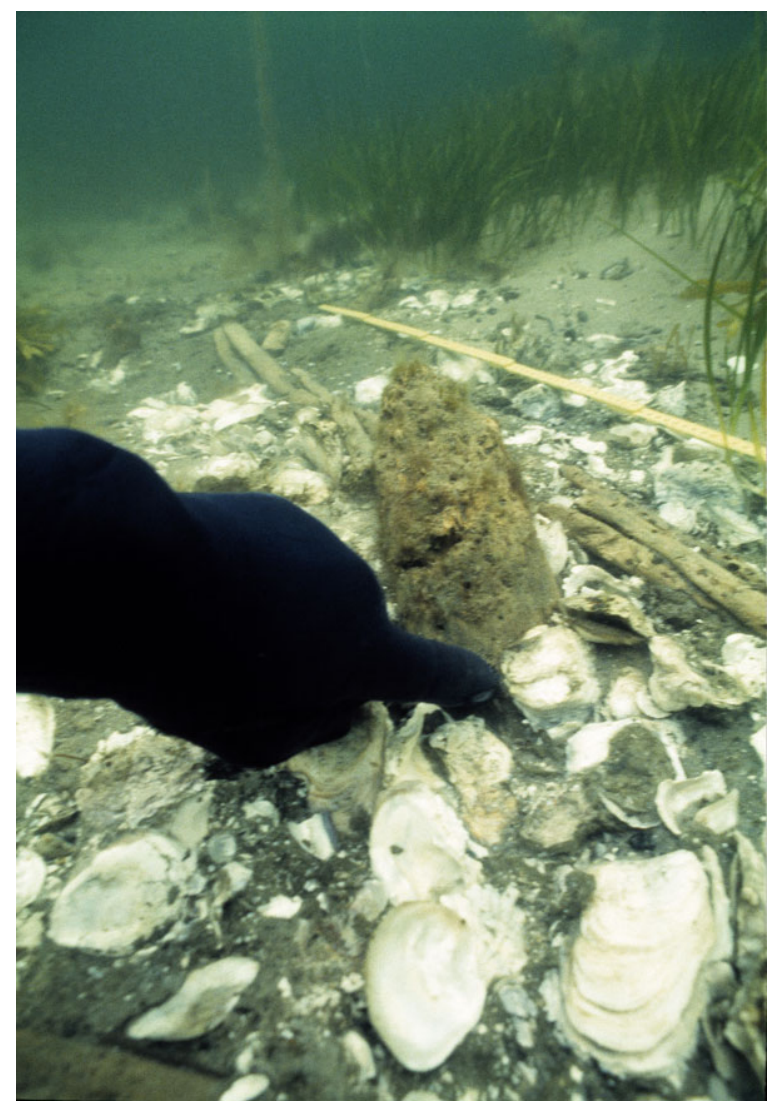

Figure 3 Wattle rods and a still vertical supporting pole of weir panel E, surrounded by shells of oyster that thrived on the fish weir during its use period in the Neolithic. The diver's finger points towards a paired set of shells from an individual still attached to a vertical pole (No. 904 in Table 1). Prior to taking the photo, a growth of algae was picked off the pole for the sake of visibility. Microscopic rootlets from this vegetation may have penetrated the outer part of the wood and subsequently become part of the samples dated. (Photo: Anders Fischer 1998.)

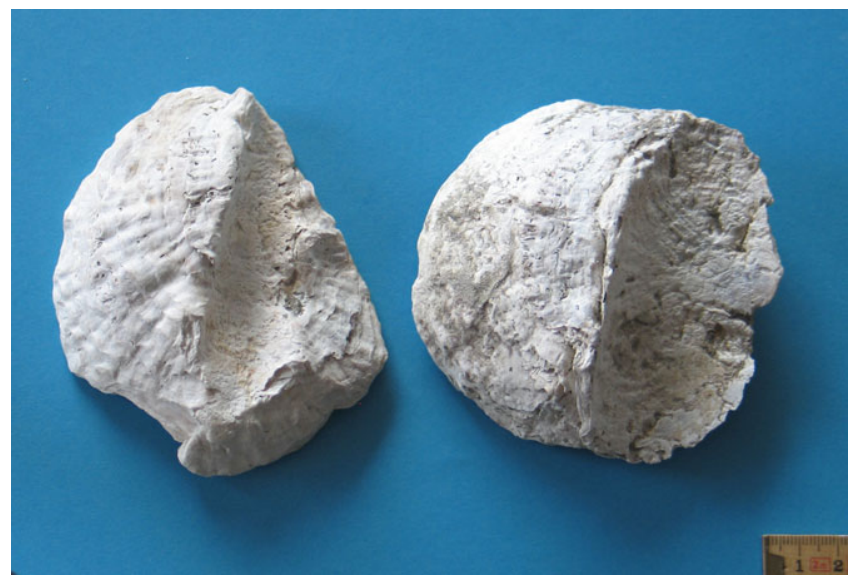

Figure 4 Stray-found oyster shells (lower/proximal valves) found near panels C1 and C2. Their surfaces show a welldefined furrow, which is the negative of the constructional wood on which these mollusks originally grew. (Photo: Anders Fischer.) 
(A)

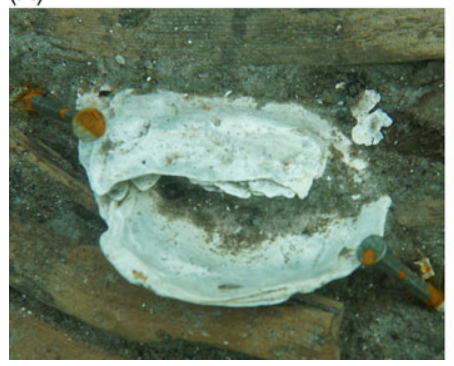

(B)

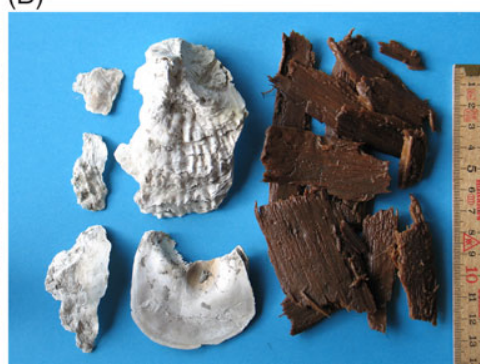

Figure 5 Examples of dated materials: (A) a paired set of oyster shells attached to the wickerwork of panel C2; (B) the lower (cupped) and upper (flat) valve of the oyster shown in Figure 3 and the outer ca. four year-rings sliced off from the pole on which the mollusk once grew. The negative of the pole is seen on the uppermost right part of the cupped valve. (Photos: Anne Marie Eriksen [A] and Anders Fischer [B].)

The strategy included a concern with what uncertainties were at play relating to biological own age, recent contamination, etc.

When removed from their in situ position each shell and each portion of constructional wood was placed in a separate plastic bag. A bit of sea water was added to the wood samples to avoid collapse of the wood structure. Subsequently standard procedures of storage under dark and cold conditions with no access for atmospheric oxygen were followed for the purpose of minimizing the growth of microorganisms. No preservatives were involved. Wood species determination was performed on micro slices of the samples observed via a standard microscope. Likewise, the season of harvest was determined on meticulously cut sections of the outermost year rings. During the subsequent slicing out the youngest year rings for radiocarbon dating an estimate was made on the average biological own age of each sample. Care was taken that the material selected did not include sediment or macroscopic biological material from present-day sea weeds, etc. Using the outermost year rings may, however, have introduced a risk that wood samples were contaminated by recent microscopic substances such as fungi, bacteria and rootlets. This risk clearly applies to a sample from panel E, taken from a vertical pole that had been eroded out of the marine gyttja and exposed directly to light and oxygen-rich sea water, most likely for several years prior to sampling (Figure 3). As to the shell samples such a risk of contamination from recent organisms was eliminated through physical and chemical purification procedures, see below.

The collection of samples for estimating the marine reservoir age at the Nekselø Wickerwork took place in two rounds. During a swift inspection of the site in 1998 a vertical pole with an intact pair of oyster shells attached to it was lifted (Figures 3 and 5B). Parts of the mollusk and the pole was shipped to the dating laboratory in Trondheim, where ${ }^{14} \mathrm{C}$ measurements of relatively small samples could be performed via the radiometric decay counting method. Panel C1 was also observed during this diving inspection. As a consequence of its special research potential it was covered with a protective top of geotextile and sand bags (Pedersen et al. 2017; Skriver et al. 2018). These were removed for a couple of days in 2016, during which parts of $\mathrm{C} 1$ and the previously unknown panel $\mathrm{C} 2$ were exposed and samples for wood anatomical analysis and AMS dating were collected (Figure 2). The resulting new samples were handed over to the AMS Centre in Aarhus.

At the dating laboratories, shell samples were mechanically cleaned and subsequently purified using demineralized water in an ultrasonic bath. Next, the outer $20-25 \%$ of the shells were 
removed using $1 \mathrm{M} \mathrm{HCl}$ at room temperature. Finally, the samples were dissolved in $80 \%$ $\mathrm{H}_{3} \mathrm{PO}_{4}$ in evacuated seal-caped glass tubes. Wood samples were pretreated using an acidbase-acid (ABA) pretreatment method $\left(1 \mathrm{M} \mathrm{HCl}, 1 \mathrm{M} \mathrm{NaOH}\right.$ at $80^{\circ} \mathrm{C}$ and lastly $1 \mathrm{M} \mathrm{HCl}$ at room temperature), and the ones dealt with at the Aarhus AMS Centre (AARAMS) were combustion in sealed evacuated quartz tubes containing $200 \mathrm{mg}$ pre-cleaned $\mathrm{CuO}$. Subsequently, they were graphitized using the $\mathrm{H}_{2}$ reduction method and an iron catalyst (e.g. Vogel et al. 1984) and ${ }^{14} \mathrm{C}$ analyzed using a $1 \mathrm{MV}$ Tandetron accelerator (cf. Olsen et al. 2017a).

The radiocarbon results (Table 1) are reported as conventional ${ }^{14} \mathrm{C}$ dates $\mathrm{BP}$ and are corrected for fractionation by normalizing to $-25 \%$ using online ${ }^{13} \mathrm{C} /{ }^{12} \mathrm{C}$ ratios (Stuiver and Polach 1977), while radiocarbon ages were converted to calendar years using OxCal 4 and IntCal20 (Ramsey et al. 2010; Reimer et al. 2020). It should be noted that the ${ }^{14} \mathrm{C}$ ages obtained for oyster shells are remarkably alike. In contrast, the dates for wood samples display larger variation-a situation that is explained by the fact that the two statistical outliers both derive from wood that had been exposed by present-day erosion and could therefore have been contaminated by microscopic material of recent date (cf. caption to Figure 3).

Reservoir ages (R) are calculated using paired samples of atmospheric and marine origin by subtracting the ${ }^{14} \mathrm{C}$ age of wood (atmospheric) samples from the ${ }^{14} \mathrm{C}$ age of shell (marine) samples. The error on these values are found using propagation of errors. Combined ${ }^{14} \mathrm{C}$ ages are calculated as weighted mean values and the validity of the weighted mean is considered using reduced $\chi^{2}$ statistics. The $\chi^{2}$ is passed if and only if $\mathrm{X} \leq \mathrm{Y}$ where $\mathrm{X}$ is the $\chi^{2}$ of the sample and $\mathrm{Y}$ the $95 \% \chi^{2}$ limit (Bevington and Robinson 2003).

Regional reservoir age offsets $(\Delta \mathrm{R})$ are calculated by resampling of the calendar year $(\theta)$ probability distribution provided by the wood samples using 5000 random points. Each of the resampled calendar years, $\theta_{i}$, is then translated into a marine ${ }^{14} \mathrm{C}$ age, $\mathrm{M}_{\mathrm{i}}$, representing the global marine ${ }^{14} \mathrm{C}$ content at calendar year $\theta_{\mathrm{i}}$. Thus $\mathrm{M}_{\mathrm{i}}$ is estimated from Marine20 as $\mathrm{M}_{\mathrm{i}}=\mathrm{N}\left(\mu_{\text {Marine20 }}\left(\theta_{\mathrm{i}}\right), \sigma_{\text {Marine20 }}\left(\theta_{\mathrm{i}}\right)\right)$ where $\mu$ and $\sigma$ are the average and uncertainty of Marine20 at calendar year $\theta_{i}$ and $\mathrm{N}$ is the normal distribution. The marine sample represented here as the shell samples are drawn from a normal distribution $\mathrm{S}=\mathrm{N}\left(\mu_{\text {Sample }}, \sigma_{\text {Sample }}\right)$ where $\mu$ and $\sigma$ are the ${ }^{14} \mathrm{C}$ value and associated error of the shell sample. $\Delta \mathrm{R}$ is then calculated as: $\Delta \mathrm{R}_{\mathrm{i}}=\mathrm{M}_{\mathrm{i}}-\mathrm{S}_{\mathrm{i}}$. The skewness and kurtosis of the resulting $\Delta \mathrm{R}$ histogram is used to estimate if the $\Delta \mathrm{R}$ probability distribution resembles a normal distribution (skewness $=0$, kurtosis $=3$ ) and if so then the $\Delta \mathrm{R}$ value is estimated as the mean and standard deviation of the individual $5000 \Delta \mathrm{R}_{\mathrm{i}}$ values. Calculations of the regional reservoir age offsets $(\Delta \mathrm{R})$ are performed using MatLab 2020 (version 9.8).

\section{CALCULATING RESERVOIR AGE}

From panels $\mathrm{C} 1+\mathrm{C} 2$ three oyster and five wood samples have been ${ }^{14} \mathrm{C}$ dated (Table 1$)$. The age determination of AAR-11619 statistically disagrees with the other four wood ${ }^{14} \mathrm{C}$ ages. For this reason, it is considered an outlier, probably a result of the above-mentioned risk of contamination by recent microscopic substances. The combined ${ }^{14} \mathrm{C}$ age of the remaining four wood samples is $4531 \pm 12{ }^{14} \mathrm{C} \mathrm{BP}\left(\chi^{2} 2.4 \leq 2.6\right)$. Correspondingly, the combined ${ }^{14} \mathrm{C}$ age of the three shell samples is $4790 \pm 17\left(\chi^{2} 0.0 \leq 3.0\right)$. Thus, for the physically connected panels $\mathrm{C} 1$ and $\mathrm{C} 2$ the age difference between marine and terrestrial samples, i.e., the reservoir age, $\mathrm{R}$, is $259 \pm 27{ }^{14} \mathrm{C}$ years. 
Table 1 Dates of oyster shells and the wood on which they once grew. The paired samples of shell and wood from panels C1 and C2 were observed in the field to be physically directly connected. They are, therefore, in principle contemporaneous. The same applies to the samples from panel E. When counting in details, the reservation has to be taken that the oysters could not begin to live before their wooden substrate had been harvested and installed. Samples marked with * are outliers and are not included in the summary statistics, written in bold font.

\begin{tabular}{|c|c|c|c|c|c|c|}
\hline \multirow[b]{2}{*}{ Panel and inventory no. } & \multicolumn{2}{|c|}{${ }^{14} \mathrm{C}$ years $\mathrm{BP}$} & \multirow{2}{*}{$\begin{array}{c}\text { Estimated biological } \\
\text { age of sample }\end{array}$} & \multirow{2}{*}{$\begin{array}{l}\text { Reservoir age } \\
\mathrm{R}\left({ }^{14} \mathrm{C} \text { years }\right)\end{array}$} & \multirow{2}{*}{$\begin{array}{l}\text { Regional reservoir age } \\
\text { offset } \Delta \mathrm{R}\left({ }^{14} \mathrm{C} \text { years }\right)\end{array}$} & \multirow[b]{2}{*}{ Lab no. } \\
\hline & Oyster & Wood & & & & \\
\hline$\overline{\mathrm{C} 1,24}$ & & $4446 \pm 39^{*}$ & $9 \pm 3$ & & & $\overline{A A R-11619}$ \\
\hline $\mathrm{C} 1,60$ & & $4510 \pm 19$ & $3 \pm 0.5$ & & & AAR-26243 \\
\hline $\mathrm{C} 1,60$ & & $4567 \pm 23$ & $6 \pm 2$ & & & AAR-29950 \\
\hline$C 1,62$ & $4789 \pm 26$ & & & & & AAR-26244 \\
\hline $\mathrm{C} 2,7$ & & $4494 \pm 25$ & $16.5 \pm 1$ & & & AAR-26245 \\
\hline $\mathrm{C} 2,7$ & & $4561 \pm 25$ & $10 \pm 3$ & & & AAR-29948 \\
\hline $\mathrm{C} 2,8$ & $4794 \pm 30$ & & $2 \pm 1$ & & & AAR-29949 \\
\hline $\mathrm{C} 2,9$ & $4788 \pm 33$ & & $2 \pm 1$ & & & AAR-26246 \\
\hline $\mathrm{C} 1+\mathrm{C} 2$ & $4790 \pm 17$ & $4531 \pm 11$ & & $259 \pm 21$ & $-243 \pm 90$ & \\
\hline E, pole 904 & & $4310 \pm 75^{*}$ & $5 \pm 2$ & & & $\mathrm{~T}-18053$ \\
\hline E, oyster on pole 904 & $4785 \pm 90$ & & $3 \pm 1$ & & & $\mathrm{~T}-18054$ \\
\hline E, oyster on pole 904 & $4793 \pm 29$ & & $3 \pm 1$ & & & AAR-29946 \\
\hline E, pole 904 & & $4485 \pm 16$ & $5 \pm 2$ & & & AAR-29947 \\
\hline $\mathbf{E}$ & $4792 \pm 47$ & $4485 \pm 16$ & & $307 \pm 32$ & $-228 \pm 84$ & \\
\hline \multicolumn{4}{|c|}{$\begin{array}{l}\text { Combination of the reservoir age, } \mathrm{R} \text {, of panels } \mathrm{C} 1+\mathrm{C} 2+\mathrm{E} \text {; on the premise } \\
\text { that panels } \mathrm{C} \text { and } \mathrm{E} \text { represent one and the same episode }\end{array}$} & $289 \pm 24$ & $-226 \pm 80$ & \\
\hline \multicolumn{4}{|c|}{$\begin{array}{l}\text { Combination of the reservoir age, } R, \text { of panels } C 1+C 2 \text { and } E \text {; on the premise } \\
\text { that panels } C \text { and } E \text { represent independent episodes }\end{array}$} & $273 \pm 18$ & $-234 \pm 61$ & \\
\hline
\end{tabular}



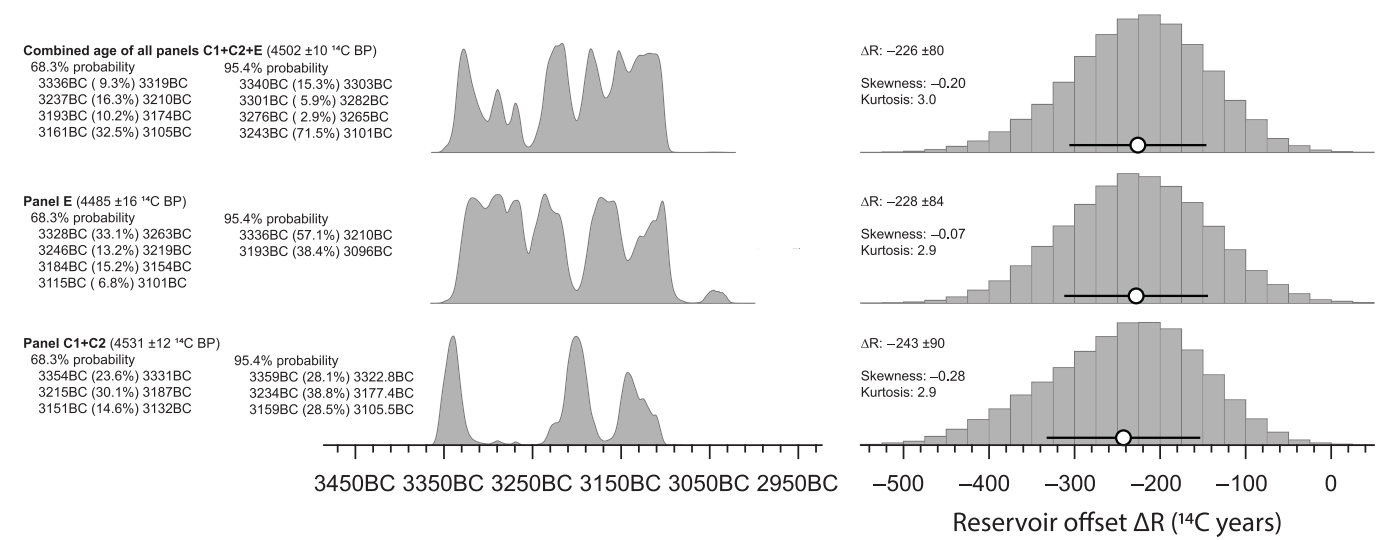

Figure 6 (Left) Calibrated probability distributions of the wood samples, using OxCal 4.4 (Ramsey et al. 2010) and IntCal20 (Reimer et al. 2020). (Right) Regional reservoir age offsets, $\Delta$ R, calculated using Marine20 (Heaton et al. 2020).

From panel E the combined value for oyster (T-18054 and AAR-29246) yields $4792 \pm 47{ }^{14} \mathrm{C}$ BP $\left(\chi^{2} 0.0 \leq 3.8\right)$. The wood sample T-18053 is for statistical reasons considered an outlier, cf. above mentioned risk of recent biological contamination. Thus, the age difference between marine and terrestrial samples for this panel is calculated $307 \pm 32{ }^{14} \mathrm{C}$ years.

In case panels $\mathrm{C} 1+\mathrm{C} 2$ and $\mathrm{E}$ represent independent-although chronologically closebuilding episodes, the combined reservoir age of these events is $273 \pm 18{ }^{14} \mathrm{C}$ years. If alternatively, panels $\mathrm{C}$ and $\mathrm{E}$ are from one and the same construction event, as would seem possible from the archaeological evidence, we reach the slightly different result of $289 \pm 24$ ${ }^{14} \mathrm{C}$ years by making a weighted average of all wood samples $\left(4502 \pm 12{ }^{14} \mathrm{C}\right.$ years, $\chi^{2}$ $9.0 \leq 9.5)$ and all shell samples $\left(4791 \pm 21{ }^{14} \mathrm{C}\right.$ years, $\left.\chi^{2} 0.0 \leq 9.5\right)$. Because, the inference of contemporaneity is open to discussion, we favor the value of $273 \pm 18{ }^{14} \mathrm{C}$ years.

The regional reservoir age offset, $\Delta \mathrm{R}$, is shown in Figure 6. The resulting skewness of the $\Delta \mathrm{R}$ histograms range between -0.28 and -0.07 indicating a tailing towards lower $\Delta R$ values in all histograms. The calculated kurtosis is close to 3 , which together with the low skewness values suggests that each $\Delta \mathrm{R}$ probability distribution can be assumed normal distributed. Hence the $\Delta \mathrm{R}$ for Panel $\mathrm{C} 1+\mathrm{C} 2$, Panel $\mathrm{E}$ and all panels combined are estimated from the mean and standard deviation of the $\Delta \mathrm{R}$ histograms and amounts to $-243 \pm 90,-228 \pm 84$ and $-226 \pm$ $80{ }^{14} \mathrm{C}$ years, respectively (Figure 6). The combined $\Delta \mathrm{R}$ value of panels $\mathrm{C} 1+\mathrm{C} 2$ and $\mathrm{E}$, assuming independent episodes, is calculated as the weighted mean of the $\Delta \mathrm{R}$ value of Panel $\mathrm{C} 1+\mathrm{C} 2$ and Panel E (Table 1).

For the Mesolithic Dragsholm double inhumation (see below) the regional reservoir offset is calculated using the terrestrial red deer bone (AAR-7417) as proxy for the calendar age probability distribution (Table 2). The combined ${ }^{14} \mathrm{C}$ age of individual $\mathrm{A}$ and $\mathrm{B}$ of $6254 \pm$ $28{ }^{14} \mathrm{C}$ years $\mathrm{BP}$ is considered the best estimate for calculating the reservoir age, $\mathrm{R}$, of 297 $\pm 43{ }^{14} \mathrm{C}$ years (Table 2). As a proxy for the marine ${ }^{14} \mathrm{C}$ content we add the reservoir age, $\mathrm{R}$, of $297 \pm 43{ }^{14} \mathrm{C}$ years to the red deer bone ${ }^{14} \mathrm{C}$ age (AAR-7417) yielding $6280 \pm 57{ }^{14} \mathrm{C}$ years BP from which we derive a $\Delta \mathrm{R}$ value of $-263 \pm 99{ }^{14} \mathrm{C}$ years (skewness $=0.0$, kurtosis $=3.0$ ). 
Table 2 Cross dates from the Late Mesolithic Dragsholm double inhumation, based on the one hand on a burial gift of terrestrial material and on the other hand human skeletal material from two females, both representing a high intake of marine food. AMS dates and stable isotope measurements from Price et al. (2007). Calculations of marine contribution to protein diet and of marine reservoir age based on the $\mathrm{C}+\mathrm{N}$ model presented in Fischer et al. (2007).

\begin{tabular}{|c|c|c|c|c|c|c|c|c|}
\hline Material sampled & $\begin{array}{l}{ }^{14} \mathrm{C} \text { age } \\
\mathrm{BP}\end{array}$ & $\begin{array}{l}\text { Age difference: } \\
\text { terrestrial vs. } \\
\text { "marine" } \\
\text { sample } \\
\left({ }^{14} \text { C years }\right)\end{array}$ & $\begin{array}{c}\delta^{13} \mathrm{C} \\
\text { VPDB } \\
(\% 0)\end{array}$ & $\begin{array}{l}\delta^{15} \mathrm{~N} \\
\text { AIR } \\
(\% 0)\end{array}$ & $\begin{array}{c}\% \\
\text { marine }\end{array}$ & $\begin{array}{l}\text { Estimated } \\
\text { reservoir age, } \\
\mathrm{R}\left({ }^{14} \mathrm{C} \text { years }\right)\end{array}$ & Contamination issues & Lab. no. \\
\hline $\begin{array}{l}\text { Spatula of terres- } \\
\text { trial bone } \\
\text { (red deer, Cervus } \\
\text { elaphus) }\end{array}$ & $5983 \pm 38$ & - & -23.5 & nd & 0 & - & $\begin{array}{l}\text { No preservatives, contact } \\
\text { with Lyma C glue? }\end{array}$ & AAR-7417 \\
\hline $\begin{array}{l}\text { Human bone, } \\
\text { individual A, }\end{array}$ & $6187 \pm 43$ & $204 \pm 57$ & -10.5 & nd & 96 & $212 \pm 60$ & $\begin{array}{l}\text { Superficial extraction of } \\
\text { bedacryl lacquer }\end{array}$ & AAR-7414 \\
\hline $\begin{array}{l}\text { 18-20 years at } \\
\text { death }\end{array}$ & $6209 \pm 40$ & $226 \pm 55$ & -10.8 & 14.0 & 94 & $241 \pm 59$ & $\begin{array}{l}\text { Intense extraction of } \\
\text { bedacryl lacquer }\end{array}$ & AAR-7414-2 \\
\hline $\begin{array}{l}\text { Human A versus } \\
\text { terrestrial bone }\end{array}$ & $\begin{array}{l}6199 \pm 29 \\
\chi^{2} 0.1 \leq 3.8\end{array}$ & $216 \pm 48$ & -10.7 & & 95 & $227 \pm 51$ & & \\
\hline $\begin{array}{l}\text { Human bone, } \\
\text { individual } \mathrm{B} \text {, }\end{array}$ & $6175 \pm 49$ & $192 \pm 62$ & -11.5 & nd & 88 & $218 \pm 70$ & $\begin{array}{l}\text { Superficial extraction of } \\
\text { bedacryl lacquer }\end{array}$ & AAR-7415 \\
\hline $\begin{array}{l}>\text { ca. } 40 \text { years at } \\
\text { death }\end{array}$ & $6296 \pm 39$ & $313 \pm 54$ & -11.7 & 13.7 & 87 & $362 \pm 63$ & $\begin{array}{l}\text { Intense extraction of } \\
\text { bedacryl lacquer }\end{array}$ & AAR-7415-2 \\
\hline $\begin{array}{l}\text { Human B versus } \\
\text { terrestrial bone }\end{array}$ & $\begin{array}{l}6249 \pm 31 \\
\chi^{2} 3.7 \leq 3.8\end{array}$ & $266 \pm 49$ & -11.6 & & 87 & $305 \pm 56$ & & \\
\hline $\begin{array}{l}\text { Average of all four } \\
\text { measurements } \\
\text { on individuals A } \\
\text { and B }\end{array}$ & $\begin{array}{l}6222 \pm 21 \\
\chi^{2} 1.8 \leq 2.6\end{array}$ & $239 \pm 44$ & & & & $\begin{array}{c}262 \pm 38 \\
\chi^{2} 1.1 \leq 3.8\end{array}$ & & \\
\hline $\begin{array}{l}\text { Average of two } \\
\text { measurements } \\
\text { on individuals A } \\
\text { and B, based } \\
\text { on intensely } \\
\text { purified samples }\end{array}$ & $\begin{array}{l}6254 \pm 28 \\
\chi^{2} 2.4 \leq 3.8\end{array}$ & $270 \pm 47$ & & & & $\begin{array}{c}297 \pm \mathbf{4 3} \\
\chi^{2} 2.0 \leq 3.8\end{array}$ & & \\
\hline
\end{tabular}




\section{DISCUSSION}

${ }^{14} \mathrm{C}$ age determinations of humans and animals, the diet of which derived partly or fully from aquatic environments, often have such a large reservoir age offset that a correction is mandatory to make use of them (e.g., Fischer 2002; Olsen et al. 2010, 2019; Wood et al. 2013; Martindale et al. 2018). When reservoir correcting and calibrating ${ }^{14} \mathrm{C}$ dates of such individuals it is necessary to reconstruct their dietary habits using stable isotope analysis (e.g. Fischer et al. 2007; Olsen et al. 2010; Fernandes et al. 2015; King et al. 2018). A further requirement is to know the reservoir age of the specific place and time accurately. We consider the reservoir age, $\mathrm{R}(\mathrm{t})$, of $273 \pm 18{ }^{14} \mathrm{C}$ years and the corresponding reservoir age offset, $\Delta \mathrm{R}(\mathrm{t})$, of $-234 \pm 61{ }^{14} \mathrm{C}$ years for The Wickerwork the currently best estimate available for the open waters of the southern Kattegat region during the neolithization period.

In this connection we return to the data from the above mentioned study conducted on samples from three fjords/inlets of the Danish archipelago (Olsen et al. 2009). If we focus not on the extremes but the medians of the reservoir age, $\mathrm{R}(\mathrm{t})$, it is interesting to note that the values for the two sites with an effective exchange of water with the open sea is $250 \pm 119{ }^{14} \mathrm{C}$ years (Horsens Fjord) and $231 \pm 46{ }^{14} \mathrm{C}$ years (Tempelkrog), while the value for the site with a more restricted water exchange is $565 \pm 57{ }^{14} \mathrm{C}$ years (Skælskør Nor) (excluding samples based on shells from the species of Scrobicularia plana and Hydrobia, which are depositfeeders, and who will therefore most likely include carbon older than their actual time of life). Consequently, a reservoir age, $\mathrm{R}(\mathrm{t})$, in the order of what is obtained from the Nekselø Wickerwork may be typical for the more ocean-exposed parts of the Danish archipelago.

The reservoir offset, $\Delta \mathrm{R}(\mathrm{t})$, of $-234 \pm 61{ }^{14} \mathrm{C}$ years is comparable with the modern (1861-1952 AD) estimates of the $\Delta R$ values around Kattegat and the Baltic Sea ranging between -170 and $-299{ }^{14} \mathrm{C}$ years (Figure 1). The recently updated Marine20 calibration curve includes carbon cycle dynamics and therefore the global reservoir age, $\mathrm{R}(\mathrm{t})$, is time variable (Heaton et al. 2020). Thus, because the carbon cycle is included in the marine calibration curve, it is tempting to conclude that the $\Delta \mathrm{R}(\mathrm{t})$ values in the Kattegat region are time invariable. However, both the modern and Neolithic $\Delta \mathrm{R}$ values are calculated for periods where the global reservoir age, $\mathrm{R}(\mathrm{t})$, is ca. $550{ }^{14} \mathrm{C}$ years, the period in-between is characterized by lower $\mathrm{R}(\mathrm{t})$ values around $465{ }^{14} \mathrm{C}$ years (Heaton et al. 2020). Additionally, the marine calibration curve represents the global ocean and in contrast the Baltic Sea and Kattegat are influenced by regional hydrological and geological processes which are not taken into account and which cannot be assumed synchronous with the changes included in Marine20 (e.g. Zillén et al. 2008). Thus, further research is needed into the $\Delta \mathrm{R}(\mathrm{t})$ variability of the Kattegat and Baltic Sea region to investigate the time dependency of the regional reservoir offset.

It is also worth returning to results from the study of a Late Mesolithic inhumation burial at Dragsholm (Petersen 1974, 2008) (not to be confused with the Early Neolithic male burial from same place, mentioned below). The site is located within the Danish archipelago and at the time of its construction it lay directly above the beach. It contained the well-preserved skeletons of two females and a burial gift made of terrestrial material - a spatula produced from bone of red deer. Samples of the skeletons and the spatula were subject to several rounds of ${ }^{14} \mathrm{C}$ dating and measuring of stable isotopes (Price et al. 2007). The $\delta^{13} \mathrm{C}$ values showed that both humans had mainly subsisted on marine food. Model-based calculations of the marine reservoir effect pertaining to them range between $212 \pm 60$ and $362 \pm 63{ }^{14} \mathrm{C}$ years (Table 2). The average reservoir age, $\mathrm{R}(\mathrm{t})$, calculated on data from the samples most intensely cleaned for 
preservatives is $297 \pm 43{ }^{14} \mathrm{C}$ years-i.e., in agreement with reservoir age values of the Wickerwork of Nekselø.

The combination of results from Dragsholm and Nekselø indicates that the marine reservoir age for these two archaeological find spots did not differ essentially during a period of several centuries around the Mesolithic-Neolithic divide. This may not be surprising, since the two sites are located within a distance of only $6 \mathrm{~km}$, and originally, they were both directly connected with/part of the Sejerø Bay. This result leads us to conclude that a relatively certain reservoir corrected radiocarbon based chronological sorting of neolithization period human skeletons from the surroundings of this bay should be possible. Among these skeletons are several that are fundamental to the current debate on the neolithization of Denmark, such as:

- Rødhals Man, who is considered a late survivor of the indigenous Mesolithic (Ertebølle Culture) population (Fischer 2002);

- Dragsholm Man, who according to his burial gifts as well as the presently available radiocarbon dates and dietary stable isotope measurements is one of the earliest known members of the local Early Neolithic farming society (Funnel Beaker Culture) (Fischer 2002);

- Early Neolithic individuals, possibly representing the elite among the local Funnel Beaker Culture population, who were interred in the Vig Femhøve dolmen (Sjögren and Fischer in prep.).

\section{CONCLUSION}

The radiocarbon assemblage from the Nekselø Wickerwork has the special quality of extensive replication of dates representing a chronologically sharply restricted event. We have six marine and eight terrestrial ${ }^{14} \mathrm{C}$ dates directly relating to one and the same incident. Consequently, it is possible to conduct in-depth source critical evaluation of age determinations to an unusual extent. In this way a solid estimate on marine reservoir age in prehistoric time has been reached: $273 \pm 18{ }^{14} \mathrm{C}$ years.

Our re-evaluation of previously produced geological and archaeological data from marine environments in the Danish archipelago north of the Baltic Sea generally indicate similar reservoir ages. We acknowledge that each point in time and space may have its own aquatic reservoir age. Based on the data presently available, we on the other hand, judge the ca. 273 years to be a more realistic estimate than the previously favored ca. $400{ }^{14} \mathrm{C}$ years when correcting for reservoir age in radiocarbon dates of neolithization period marine samples from open sea exposed sites in the Danish archipelago. The reservoir age estimate from the Wickerwork is directly applicable in culture-historical and genetic studies of human skeletons and burials essential to the ongoing debate of the neolithization of Southern Scandinavia.

\section{ACKNOWLEDGMENTS AND CREDITS}

The Nekselø Wickerwork is recorded in the Danish Agency for Palaces and Culture's national register of sites and monuments under number 401263-3. Field observations mentioned are primarily thanks to a registration and condition assessment program for underwater cultural heritage, conducted under the auspices of the National Forest and Nature Agency, 
Denmark. Some of the samples presented in the present paper were salvaged during these activities of the 1990s. Others were brought to the surface thanks to a subsequent condition assessment project, organized by David Gregory of the Danish National Museum in cooperation with the first author of the present paper. The latter activity was funded by the Danish Agency for Palaces and Culture. We thank Torben Malm of the mentioned agency for his leading role in the practical work of revealing wattle sections $\mathrm{C} 1$ and $\mathrm{C} 2$. Additionally, Anne Marie Eriksen of the National Museum of Denmark is thanked for photo documentation and participation in the partial excavation of these two wattle sections in 2016. Likewise, we thank Thomas Bartholin for wood anatomical determinations of samples from the Nekselø Wickerwork, Steinar Gulliksen for the analytical activities conducted at the Trondheim Radiocarbon dating laboratory, and Nicky Milner for advice on estimating biological age of oyster shells. Peter Moe Astrup of Moesgaard Museum kindly informed us on finds conditions etc. of two charcoal samples from Hjarnø Sund, discussed in the text. Moreover, we thank Rich Potter of University of Gothenburg's Department of Historical Studies, for producing Figure 1, including the integration of its part B, which was originally produced by Thomas Eriksen of the Danish Agency for Culture on the basis of the Danish Cadastra Office's ortophoto from 1999. Additionally, Karl-Göran Sjögren, Douglas Price and an anonymous peer reviewer are thanked for critical reading and constructional commenting on previous versions of the manuscript.

The paper is a spin-off from a genetical cum archaeological project directed by Eske Willerslev and Kristian Kristiansen, funded by Svenska Riksbankens Jubileumsfond, within the project "Towards a new European Prehistory. Integrating aDNA, isotopic investigations, language and archaeology to reinterpret key processes of change in the prehistory of Europe".

\section{REFERENCES}

Andersen SH. 1991. Norsminde. A "køkkenmødding" with late mesolithic and early neolithic occupation. Journal of Danish Archaeology 8:13-40.

Andersen SH. 1993. Bjørnsholm. A Stratified Køkkenmødding on the Central Limfjord, North Jutland. Journal of Danish Archaeology 10: 59-96.

Ascough PL, Cook GT, Dugmore AJ. 2009. North Atlantic marine ${ }^{14} \mathrm{C}$ reservoir effects: Implications for late-Holocene chronological studies. Quaternary Geochronology 4:171-180.

Bartholin T. 1996. Den neolitiske hasselskov. In: Slotte H, Göransson H, editors Lövtäkt och Stubbskottsbruk. Människans förändring av landskabet - boskatsskötsel och åkerbruk med hjälp av skog. Stockholm: Kungliga Skogs- och Lantbruksakademien. p. 453-457.

Bevington PR, Robinson DK. 2003. Data reduction and error analysis for the physical sciences. 3rd ed. Boston, MA: McGraw-Hill.

Brinkhuizen DC. 1983. Some notes on recent and Preand Protohistoric fishing gear from Northwestern Europe. Paleohistoria 25:7-53.

Christensen JT, Cedhagen T, Hylleberg J. 2004. LateHolocene salinity in Limfjorden, Denmark. Sarsia 89:379-387.
Fernandes R, Grootes P, Nadeau MJ, Nehlich O. 2015. Quantitative diet reconstruction of a Neolithic population using a Bayesian mixing model (FRUITS): The case study of Ostorf (Germany). American Journal of Physical Anthropology 158(2):325-340.

Fischer A. 2002. Food for Feasting? An evaluation of explanations of the neolithisation of Denmark and southern Sweden. In: Fischer A, Kristiansen K, editors. The Neolithisation of Denmark - 150 Years of Debate. Sheffield Archaeological Monographs 12. J.R. Collis Publications, Sheffield. p. 343-393.

Fischer A. 2006. Fiskeri i lange baner. In: Pedersen L, editor. Årets gang på Kalundborg og Omegns Museum 2005. Kalundborg Museum, Kalundborg. p. 70-75.

Fischer A. 2007. Coastal fishing in Stone Age Denmark - evidence from below and above the present sea level and from human bones. In: Milner $\mathrm{N}$ et al., editors. Shell Middens in Atlantic Europe. Oxford: Oxbow. p. 54-69.

Fischer A. 2011. Stone Age on the continental shelf: an eroding resource. In: Benjamin $\mathrm{J}$, Bonsall $\mathrm{C}$, Pickard C, Fischer A, editors. Submerged Prehistory. Oxford: Oxbow Books. p. 298-231. 
Fischer A, Jensen TTZ. 2018. Radiocarbon dates for submarine and maritime finds from early prehistory. In: Fischer A, Pedersen L, editors. Oceans of archaeology. Højbjerg: Jutland Archaeological Society. p. 202-221.

Fischer A, Kristiansen K. editors 2002. The Neolithisation of Denmark - 150 years of debate. Sheffield Archaeological Monographs 12. Sheffield: J.R. Collis Publications.

Fischer A, Olsen J, Richards M, Heinemeier J, Sveinbjörnsdóttir ÁE, Bennike P. 2007. Coastinland mobility and diet in the Danish Mesolithic and Neolithic: evidence from stable isotope values of humans and dogs. Journal of Archaeological Science 34:2125-2150.

Gregory D, Matthiesen H. 2018. Deterioration and preservation of organic materials on the seabed. In: Fischer A, Pedersen L, editors Oceans of Archaeology. Højbjerg: Jutland Archaeological Society. p. 136-143.

Heaton TJ, Köhler P, Butzin M, Bard E, Reimer RW, Austin WEN, Ramsey CB, Grootes PM, Hughen KA, Kromer B, et al. 2020. Marine20-the marine radiocarbon age calibration curve $(0-55,000$ cal BP). Radiocarbon 62:779-820.

Heier-Nielsen S, Heinemeier J, Nielsen HL, Rud N. 1995. Recent reservoir ages for Danish fjords and marine waters. Radiocarbon 37:875-882.

Heinemeier J, Nielsen SH, Rud N. 1993. Danske AMS ${ }^{14} \mathrm{C}$ dateringer, Århus 1992 (summary in English). Arkæologiske Udgravninger i Danmark 1992. Copenhagen: Det Arkæologiske Nævn. p. 291-303.

Håkansson S. 1969. University of Lund Radiocarbon Dates II. Radiocarbon 11:430-450.

King CL, Snoddy AM, Millard AR, Grocke DR, Standen VG, Arriaza BT, Halcrow SE. 2018. A multifaceted approach towards interpreting early life experience and infant feeding practices in the ancient Atacama Desert, Northern Chile. International Journal of Osteoarchaeology 28(5): 599-612.

Larsen JS, Philippsen B, Skriver C, Astrup PM, Borup P, Mannino MA. 2018. From oysters to cockles at Hjarnø Sund: Environmental and subsistence changes at a Danish Mesolithic site. Radiocarbon 60:1-13.

Lewis JP, Ryves, DB, Rasmussen P, Olsen J, Knudsen K-L, Andersen SH, Weckström K, Clarke AL, Andrén E, Juggins S. 2016. The shellfish enigma across the MesolithicNeolithic transition in southern Scandinavia. Quaternary Science Reviews 151:315-320.

Lewis JP, Ryves DB, Rasmussen P, et al. 2020. Marine resource abundance drove pre-agricultural population increase in Stone Age Scandinavia. Nat. Commun. 11, 2006. doi: 10.1038/s41467-02015621-1.
Lougheed BC, Filipsson HL, Snowball I. 2013. Large spatial variation in coastal ${ }^{14} \mathrm{C}$ reservoir age $-\mathrm{a}$ case study from the Baltic Sea. Climate of the Past 9(3):1015-1028. doi: 10.5194/cp-9-10152013.

Martindale A, Cook GT, McKechnie I, Edinborough K, Hutchinson I, Eldridge M, Supernant K, Ames KM. 2018. Estimating marine reservoir effects in archaeological chronologies: comparing delta R calculations in Prince Rupert Harbor, British Columbia, Canada. American Antiquity 83(4):659-680.

Milner N. 2002. Incremental growth of the European oyster, Ostrea edulis: seasonality information from Danish kitchenmiddens. Department of Archaeology, University of Newcastle.

Nielsen PO. 1993. The Neolithic. In: Hvass S, Storgaard B, editors. Digging into the past. 25 years of archaeology in Denmark. Copenhagen: The Royal Society of Northern Antiquaries. p. 84-87.

Olsen J, Rasmussen P, Heinemeier J. 2009. Holocene temporal and spatial variation in the radiocarbon reservoir age of three Danish fjords. Boreas 38:458-470. doi: 10.1111/j.1502-3885.2009.00088.x.

Olsen J, Heinemeier J, Lübke H, Lüth F, Terberger T. 2010. Dietary habits and freshwater reservoir effects in bones from a Neolithic NE German cemetery. Radiocarbon 52:635-644.

Olsen J, Tikhomirov D, Grosen C, Heinemeier J, Klein M. 2017a. Radiocarbon analysis on the new Aarams 1MV tandetron. Radiocarbon 59:905-913.

Olsen J, Ascough P, Lougheed BC, Rasmussen P. 2017b. Radiocarbon dating in estuarine environments. In: Weckström K, Saunders KM, Gell PA, Skilbeck CG, editors. Applications of paleoenvironmental techniques in estuarine studies. Dordrecht: Springer. p. 141-170.

Olsen J, Dahlström H, Poulsen B. 2019. The chronology of medieval Copenhagen. Radiocarbon 61:1675-1683.

Olsson IU. 1980. Content of ${ }^{14} \mathrm{C}$ in marine mammals from northern Europe. Radiocarbon 22:662-675.

Pedersen L. 1995. 7000 years of fishing: stationary fishing structures in the Mesolithic and afterwards. In: Fischer A, editor. Man and sea in the Mesolithic: coastal settlement above and below present sea level. Oxford: Oxbow Books. p. $75-86$.

Pedersen L. 1997. They put fences in the sea. In: Pedersen L, Fischer A, Aaby B, editors. The Danish Storebælt since the Ice Age - man, sea and forest. Copenhagen: Storebælt Fixed Link. p. 124-143.

Pedersen L. 2013. Eelers in Danish waters interaction between men and their marine environment over 8000 years. In: Daire M-Y, Dupont C, Baudry A et al., editors. Ancient maritime communities and the relationship 
between people and environment along the European Atlantic coasts. BAR International Series 2570. Oxford: Archaeopress. p. 163-173.

Pedersen L, Jørgensen G. 2006. Med amatørarkæologerne i arbejdsmarken. In: Pedersen L, editor. Årets gang på Kalundborg og Omegns Museum 2005. p. 58-59.

Pedersen L, Fischer A, Gregory J. 2017. Fletværket ved Nekselø - skovdrift og storstilet fiskeri i bondestenalderen. (English summary: The Wickerwork off Nekselø - forestry and largescale fisheries in the Neolithic.) Nationalmuseets Arbejdsmark 2017:134-145.

Pedersen L, Fischer A, Bartholin T. 2018. Nekseløfishing and woodland management on a grand scale. In: Fischer A, Pedersen L, editors. Oceans of archaeology. Højbjerg: Jutland Archaeological Society. p. 86-87.

Persson P. 1999. Neolitikums början. Undersökningar kring jordbrukets introduktion i Nordeuropa. Gothenburg: University of Gothenburg.

Petersen EB. 1974. Gravene ved Dragsholm. Fra jægere til bønder for 6000 år siden. Nationalmuseets Arbejdsmark:112-120.

Petersen EB. 2008. Warriors of the Neolithic TRBCulture. In: Sulgostrowska Z, Tomaszewski AJ, editors. Man - millenia - environment. Studies in honor of Romuald Schild. Warsaw: Polish Academy of Sciences. p. 33-38.

Petersen KS. 1975. Om Limfjordens postglaciale marine udvikling og niveauforhold, belyst ved mollusk-faunaen og C-14 dateringer. D.G.U. årbog 1975:75-103.

Philippsen B, Olsen J, Lewis J, Rasmussen P, Ryves D, Knudsen KL. 2013. Mid- to late-Holocene reservoir-age variability and isotope-based palaeoenvironmental reconstruction in the Limfjord, Denmark. The Holocene 23:1015-1025.

Philippsen B. 2018. Reservoir effects in a Stone Age fjord on Lolland, Denmark. Radiocarbon 60(2):653-665.

Price TD et al. 2007. New information on the Stone Age graves at Dragsholm, Denmark. Acta Archaeologica 78(2):193-219.

Ramsey BC, Dee M, Lee S, Nakagawa T, Staff R. 2010. Developments in the calibration and modelling of radiocarbon dates. Radiocarbon 52(3):953-961.

Rasmussen KL. 2013. Radiocarbon dates from Tybrind Vig. In: Andersen SH, editor. Tybrind Vig, submerged Mesolithic settlements in Denmark. Jutland Archaeological Society. Højbjerg, p. 363-364.

Reimer PJ, Baillie MGL, Bard E, Bayliss A, Beck JWP, Blackwell G, Ramsey CB, Buck CE, Burr GS, Edwards RL, Friedrich M, et al. 2009. IntCa109 and Marine09 radiocarbon age calibration curves, 0-50,000 years cal BP. Radiocarbon 51(4):1111-1150.
Reimer PJ, Bard, E, Bayliss A, et al. 2013. IntCal13 and Marine13 radiocarbon age calibration curves $0-50,000$ years cal BP. Radiocarbon 55(4):1869-1887.

Reimer P, Austin W, Bard E, et al. 2020. The IntCal20 Northern Hemisphere radiocarbon age calibration curve (0-55 cal kBP). Radiocarbon 62(4):725-757. doi: 10.1017/RDC.2020.41.

Schmelling A. 1971. Humlebæk Fiskerleie. Reprint from Årbog for 1971 for Frederiksborg Amts Historiske Samfund. Hillerød.

Sjögren KG, Fischer A. in prep. The chronology of Danish dolmens. Results from ${ }^{14} \mathrm{C}$ dates on human bones. Submitted to Journal of Neolithic Archaeology.

Skriver C, Galili E, Fischer A. 2018. Threats to the submerged prehistoric cultural heritage. In: Fischer A, Pedersen L, editors. Oceans of Archaeology. Højbjerg: Jutland Archaeological Society. p. 122-133.

Stuiver M, Polach HA. 1977. Discussion: reporting of ${ }^{14} \mathrm{C}$ data. Radiocarbon 19(2):355-363.

Stuiver M, Pearson GW, Braziunas T. 1986. Radiocarbon age calibration of marine samples back to 9000 cal yr BP. Radiocarbon 28:980-1021.

Stuiver M, Braziunas TF. 1993. Modeling atmospheric ${ }^{14} \mathrm{C}$ influences and ${ }^{14} \mathrm{C}$ ages of marine samples to 10,000 BC. Radiocarbon 35:137-189.

Sørensen L. 2014. From Hunter to Farmer in Northern Europe. Migration and adaptation during the Neolithic and Bronze Age. Oxford: Wiley. Acta Archaeologica Supplementa 85(1).

Tauber H. 1981a. ${ }^{13} \mathrm{C}$ evidence for dietary habits of prehistoric man in Denmark. Nature 292(5821): 332-333.

Tauber H. 1981b. Kostvaner i forhistorisk tid - belyst ved C-13 målinger. In: Egevang $\mathrm{R}$ et al., editors. Det Skabende Menneske. Kulturhistoriske skitser tilegnet P.V. Glob 20. februar 1981(1). Herning: Nationalmuseet. p. 112-126.

Tauber H. 1990. Danske arkæologiske C-14 dateringer, København 1989. Arkæologiske Udgravninger i Danmark 1989. Copenhagen: Det Arkæologiske Nævn. p. 225-240.

Vogel JS, Southon JR, Nelson DE, Brown TA. 1984. Performance of catalytical condensed carbon for use in accelerator mass spectrometry. Nuclear Instruments \& Methods in Physics Research B 5:289-293.

Wood RE, Higam TFG, Buzilhova A, Suvorov A, Heinemeier J, Olsen J. 2013. Freshwater radiocarbon reservoir effects at the burial ground of Minino, north west Russia. Radiocarbon 55(1):163-177.

Zillén L, Conley DJ, Andrén T, Andrén E, Björck S. 2008. Past occurrences of hypoxia in the Baltic Sea and the role of climate variability, environmental change and human impact. Earth-Science Reviews 91(1-4):77-92. 